\title{
NON-PERFORMING ASSETS A BIGGEST CHALLENGE IN BANKING SECTOR-A COMPARATIVE STUDY BETWEEN INDIA AND BANGLADESH BANKING SECTOR
}

\author{
Sudin Bag ${ }^{1}$ and Sajijul Islam ${ }^{2}$ \\ Department of Business Administration, Vidyasagar University, India
}

\begin{abstract}
Non-Performing Assets (NPAs) are important and challenging issue in the banking sector nowadays. It is quite uncontrollable and strong virus which badly affecting the health of banking sector and also economy of the nations. Non-Performing Assets are also commonly known as Non-Performing Loans (NPLs). Non-Performing Assets are like a blunt weapon in banking sector. It does not generate any income, whereas, the bank is required to make provisions such as assets. The problem of NPA is not limited to only any particular nation's banks, but it prevails in the entire banking industry in the world. There are many researchers have been focused on the issues regarding the NPAs. The aims of this paper are to analyze the recent trend of NPAs in banking with reference to India and Bangladesh and also to find out the relationship between NPAs and profitability. The present study is based on the secondary data which have been collected from the report of RBI and website of the State Owned bank as well as private bank of Bangladesh from the year 2010-2016. The researchers considered ten banks from each of the countries and make a blend of public private banks for this study. The researcher has used SPSS-22 for analyzing the data and interpreted accordingly.
\end{abstract}

Keywords:

NPAs, Uncontrollable, Bank, Profitability, Trends

\section{INTRODUCTION}

In the era of globalization, the business houses are keen to reach in the global market and ensure the maximum return from their investment. To enter into business and or any business related activities the minimum and foremost criteria is capital. The capital can be broadly explained as owned capital and loan capital. Owned capital is basically the own fund in the business which is very small amount of the total investment. The rest is termed as loan capital. Bank is the main source of loan capital in the business. Banks are plying vital role in the society. In the development of the country's economic growth, banking system is an essential consideration. Bankers are the custodian and distributors of the liquid cash and capital in a country like India and Bangladesh. The main function of bank is to mobilize the public deposits and lending to the existing business houses as well the new entrepreneurs for the development of the nation's industrial and economic progress. Since the independence the Indian banking sector as well as Bangladesh banking sectors is trying to retrieve the economy from the trap of the under development and use some anti-poverty vaccine to reduce poor from the society. During this process of development, bank has facing a big challenge that is known as management of nonperforming assets (NPAs).

Bank has been set up with the aims of lending loans and mobilizes the fund in the society. Loan is an asset for a bank because the interest received and repayments of principal create a stream of cash flow and interest also leads to making profit of the bank. But, management of loans and advances are becoming a horrible task in the banking sector all over the world. The country India and Bangladesh are not except from it. The number of defaulters as well as the loan and/ advances amount in banking sector increases day by day. The apex body of banking sector Reserve Bank of India (RBI) of India and Bangladesh Bank (BB) of Bangladesh have been recommended various steps to reduce NPAs for both the countries. But till the virus NPA is in significantly active and foremost headache for both the countries because it has dual effects like generate of income from this advances are ceases and bank has to create a provisions for loan losses which are set aside to cover potential losses. Once the actual losses from defaulted loans/ advances are determined, they are written off against earnings.

\section{CONCEPT OF NPAS OR NPLS}

- The balance sheet of a bank represents various kinds of assets like cash balances in hand, investment, advances and so on. The concept of NPA is very interesting and it is restricted to loans and advances. The bank has issue loan with the aim of earning interest. If an asset generates satisfactory income and does not disclose any unusual risk except the commercial risk it is coined as performing assets. When the asset fails to generate income, is term as NonPerforming assets.

- In other words, A Non-Performing Asset (NPA) [3] [5] is defined as a credit facility in respect of which the interest and/or instalment of principal has remained "past due" for a specified period of time.

- In India, the concept of NPAs has changed over time. According to the Narasimham Committee Report, NPAs are those assets for which the interest and/or instalment of principal remains unpaid for a period of 180 days. But With an aim of moving towards the global best practices and ensuring greater transparency, a standard criterion of "90 days" overdue norm was fixed for identification of NPA from the FY March, 2004 in the Indian financial system. Thus, as per present convention, a non-performing asset refers to a loan or an advance where:

- Interest and/or instalment of principal remain overdue for a period of more than 90 days in respect of a term loan,

- The account remains "out of order" for a period of more than 90 days, in respect of an Overdraft/Cash Credit (OD/CC),

- The bill remains overdue for a period of more than 90 days in the case of bills purchased and discounted,

- Interest and/or instalment of principal remains overdue for two harvest seasons but for a period not exceeding two half 
years in the case of an advance granted for agricultural purposes, and

- Any amount to be received remains overdue for a period of more than 90 days in respect of other accounts.

\section{REVIEW OF LITERATURE}

The Non-Performing assets or Non-Performing loans are an important and debated issue in many academic literatures in the world. A good number of researchers have been enlightened the issue of NPAs. NPA as a severe threat for the existence and stability of Indian banking and demanded more proactive and curative measures to manage it.

The immediate consequence of large amount of NPLs in the banking system is bank failure as well as economic slowdown. The causes of NPLs are usually attributed to the lack of effective monitoring and supervision on the part of banks, lack of effective lenders' recourse, weaknesses of legal infrastructure, and lack of effective debt recovery strategies [1].

A Committee on Banking Sector Reforms known as Narasimham Committee was set up by RBI to study the problems faced by Indian banking sector and to suggest measures revitalize the sector. The committee identified NPA as a major threat and recommended prudential measures for income recognition, asset classification and provisioning requirements. These measures embarked on transformation of the Indian banking sector into a viable, competitive and vibrant sector. The committee recommended measures to improve "operational flexibility" and "functional autonomy" so as to enhance "efficiency, productivity and profitability" [8]-[11].

Selvarajan and Vadivalagan [4] highlighted that the management of Indian Bank must pay special attention towards the NPA management and take appropriate steps to arrest the creation of new NPAs, besides making recoveries in the existing NPAs. Timely action is essential to ensure future growth of the Bank.

In an analytical study, Lata [6] investigates the significant linkage between Non-Performing Loans (NPLs) and profitability of the SCBs in Bangladesh. She also stated that it is time to formulate appropriate rules on lending policy, credit policy, interest rate adjustment, risk management strategy etc. on all scheduled banks operating in our country. Some other relevant as well emergency precautions can be initiated by the authority as soon as possible to ensure a sound environment in banking industry of Bangladesh.

There are several reasons of nonperforming loan. But recently fund diversion, political instability, aggressive banking, fall in real estate business, weak monitoring, lack of coordination among related parties are aggravating Non-Performing loan. Strong and regular monitoring, cooperation among related parties and strict enforcement of existing laws help to reduce NPLs. Bangladesh Bank should play a vital role in these issues. Commercial banks should ensure transparency in credit granting and Bangladesh Bank should ensure that the application of credit sanctioning guidelines is being followed to issue new loan. To reduce NPLs, proper steps must be taken for debt recovery and new investment must be safe and sound. Otherwise large amount of NPLs reduce banks profitability and may erode capital also. That may bring human created disaster in banking industry [2].

Laveena and Kumar [7], made a comparative study of management of non-performing assets of the public and private sector banks of India. The study was based on the secondary data for the period 2001 to 2010 . It was found from the study that the profitability of the banks get affected by the non-performing assets. Public banks are more affected by the poor management of NPA than private sector banks. It was also found from the study that the level of NPA is higher in public sector banks than private sector banks. It was suggested by the researcher that the credit evaluation policy of the banks should be improved to reduce the level of NPA in the banks.

\section{OBJECTIVES OF THE PRESENT STUDY}

- To understand the concept of nonperforming assets of Indian Bank as well as Bangladesh Bank.

- To measure the trend of NPA in during the last seven years.

- To analyze the impact of Nonperforming assets on Return on Asset and Return on Equity on profitability of Indian as well as Bangladesh Banks.

\section{HYPOTHESIS OF THE STUDY}

$\mathrm{H}_{0}$ : There is no significant relationship between nonperforming assets and return on asset as well as Return on Equity on profitability of Indian Bank as well as ten Bangladesh Bank.

Regression Model 1a: $R O A_{I}=\alpha+\beta$.NPA $+\varepsilon$

Regression Model 1b: $R O E_{I}=\alpha+\beta$.NPA $+\varepsilon$

where, Dependent Variables are ROA \& ROE and Independent Variables is NPA.

Regression Model 2a: $R O A_{B}=\alpha+\beta$.NPA $+\varepsilon$

Regression Model 2b: $R O E_{B}=\alpha+\beta$.NPA $+\varepsilon$

where, Dependent Variables are ROA and $R O E$ and Independent Variables is NPA.

\section{RESEARCH METHODOLOGY}

To ascertain the above mentioned objectives, researchers used secondary data which has been collected from the published report of Reserve Bank of India (RBI), annual report of listed public and private sector bank in India. Financial stability Report of Bangladesh Bank for State owned Commercial banks and private Commercial banks of Bangladesh. Researchers have taken ten banks namely, Bank of Baroda, Bank of India, Canara Bank, Central Bank and Dena Bank, Axis bank, ICICI bank, IndusInd bank, Karur Vysya and Yes Bank from Indian banking sector. Out of these ten Indian banks, first five banks are belongs to the public sector category and rest are the under the category of private leading banks in India. To compare the effects of NPAs the researchers also consider ten banks from Bangladesh banking sector these are Agrani Bank, Janata Bank, Pubali Bank, AB Bank, The City Bank, Uttara Bank, Eastern, Southern Bank, National Bank and Dhaka bank for this study. The study period is from 2010-11 to 2015-2016. Researchers have performed 
regression analysis to predicting the effects of NPAs on Bank's profitability of India and Bangladesh. Profitability of the banking sector are measured by two important dimensions namely, Return on Assets (ROA), Return on Equity (ROE) The Non-Performing assets of this study are measured by NNPAs ratio (Net NonPerforming Assets to Net Advances). Profitability ratios have been taken as dependent variables and on the other hand NNPAs have been considered as independent variables in the regression analysis of this study. $R O A_{I}$ and $R O E_{I}$ are represented Return on Assets $(R O A)$ and Return on Equity $(R O E)$ of Indian banks where as $R O A_{B} \& R O E_{B}$ are indicates the Return on Assets $(R O A)$, Return on Equity ( $R O E)$ of Bangladesh banks.

\section{DATA ANALYSIS AND INTERPRETATION}

In this section, the researchers analysed the secondary data in order to fulfil the above mentioned objectives. The diagram shows the present trends of NPAs in listed public and private sector banks in India.

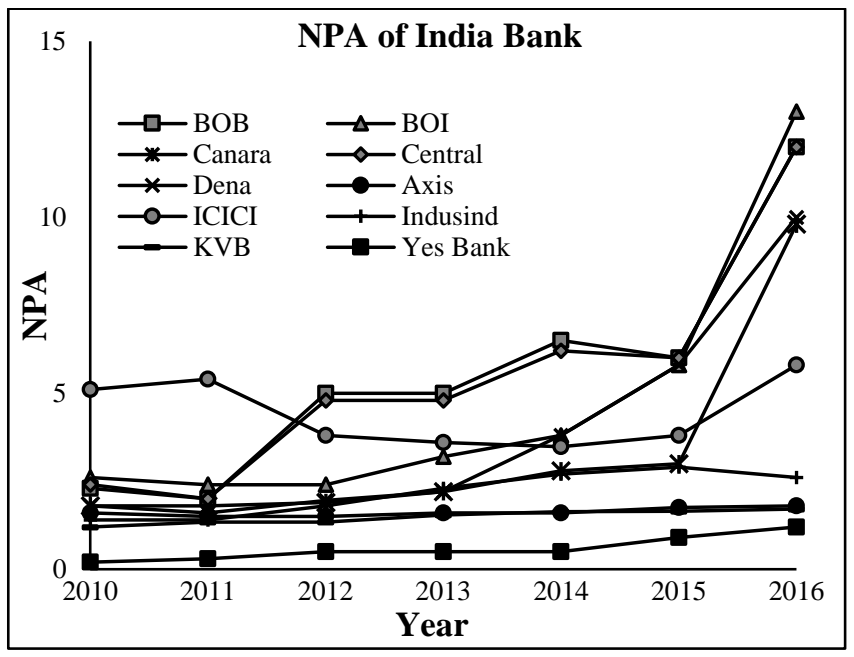

Fig.1. Trends of NPAs in Indian Banks

The Fig.1 represents the trends of Non-Performing Assets (NPAs) for the listed Indian banks for the period of 2010-11 to 2016-17. It is very significant and clearly depicted in the above picture that NPAs are continuously upward rising of the public sector banks in India during last seven years and NPAs have been increased 4 times approximately i.e., total advances of public sector is sky rocketing. On the other side, the trends of NonPerforming Assets (NPAs) for the listed Indian private sector banks are significantly stable during the study period. Thus, the positions of NPAs of private sector banks are more favourable towards the development of banks in India and most of the private banks are managing their advances in a systematic and efficient manner. Therefore, it can be concluded that public sector banks are rigorously effecting for the NPAs and continuously scarifying the profitability for these advances.

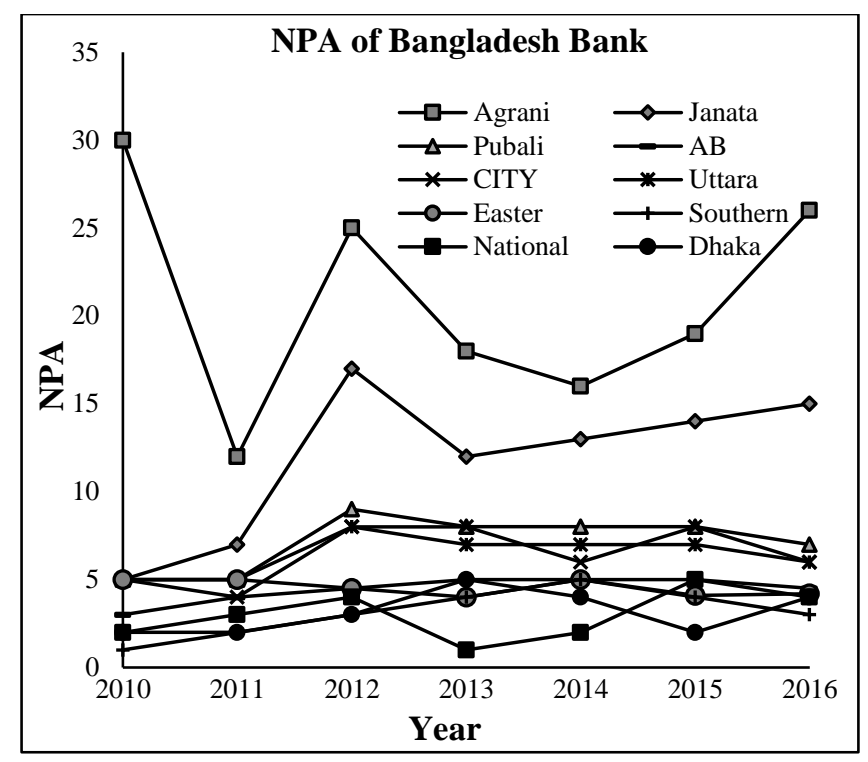

Fig.2. Trends of NPAs in Bangladesh Banks

The Fig. 2 represents the trends of Non-Performing Assets (NPAs) for the listed Bangladesh banks for the period of 2010-11 to 2016-17. It is very significant and clearly depicted in the above picture that NPAs are continuously upward rising of the state owned banks in Bangladesh except Pubali bank. The scenario of NPAs in Pubali is quite surprising and it is efficiently managed the total advances during last seven years. Whereas the trends of Non-Performing Assets (NPAs) for the listed Bangladesh private banks are offering advances in a same rate through the study periods, except the National Bank. There is a dramatic increases of the total advances as well as the NPAs has been clearly depicted in the above diagram in case of National Bank. Thus, the positions of NPAs of private sector banks are more favorable towards the development of banks in Bangladesh and most of the private banks are managing their advances in a systematic and efficient manner.

Table.1. Regression Result for Indian Banks

\begin{tabular}{|c|c|c|c|c|c|c|}
\hline \multirow{2}{*}{\multicolumn{2}{|c|}{ Model }} & \multicolumn{2}{|c|}{$\begin{array}{c}\text { Unstandardized } \\
\text { Coefficients }\end{array}$} & \multirow{2}{*}{\begin{tabular}{|c}
$\begin{array}{c}\text { Standardized } \\
\text { Coefficients }\end{array}$ \\
Beta
\end{tabular}} & \multirow{2}{*}{$\mathbf{t}$} & \multirow{2}{*}{ Sig. } \\
\hline & & $\mathbf{B}$ & $\begin{array}{l}\text { Std. } \\
\text { Error }\end{array}$ & & & \\
\hline $\begin{array}{c}\text { Research } \\
\text { Model } \\
\text { 1a }\end{array}$ & $\begin{array}{c}\text { (Constant) } \\
\text { NPA }\end{array}$ & $\begin{array}{l}7.213 \\
-.264\end{array}$ & $\begin{array}{l}.186 \\
.021\end{array}$ & -.985 & $\begin{array}{c}38.816 \\
- \\
12.866\end{array}$ & .000 \\
\hline \multicolumn{7}{|c|}{$\mathrm{R}=.985, \mathrm{R}$ square $=.971, \mathrm{~F}=165.528, \mathrm{P}$ value $=.000$} \\
\hline \multicolumn{7}{|c|}{$\mathrm{DV}=\mathrm{ROA}, \mathrm{IV}=\mathrm{NPA}$} \\
\hline $\begin{array}{c}\text { Research } \\
\text { Model } \\
\text { 1b }\end{array}$ & $\begin{array}{c}\text { (Constant) } \\
\text { NPA }\end{array}$ & $\begin{array}{c}21.450 \\
-.857\end{array}$ & $\begin{array}{c}1.164 \\
.129\end{array}$ & -.948 & $\begin{array}{l}18.422 \\
-6.660\end{array}$ & $\begin{array}{l}.000 \\
.001\end{array}$ \\
\hline \multicolumn{7}{|c|}{$\mathrm{R}=.948, \mathrm{R}$ square $=.899, \mathrm{~F}=44.351, \mathrm{P}$ value $=.001$} \\
\hline \multicolumn{7}{|c|}{$\mathrm{DV}=\mathrm{ROE}, \mathrm{IV}=\mathrm{NPA}$} \\
\hline
\end{tabular}

The Table. 1 shows the results of regression analysis of listed Indian Public Sector Banks. The Research model 1a represented the output of regression analysis, where the dependent variable (DV) is Return on Assets (ROA) and independent variable (IV) is 
ratio of Net NPA to Net advances (NPA). The model is: $R O A_{I}=$ $\alpha+\beta(\mathrm{NPA})+\varepsilon$.

The $\mathrm{F}$ value of this model is 165.528 , which is significant at $1 \%$ level of significance. The $\mathrm{R}$ value (.985) indicates that high correlation between variables and value of $\mathrm{R}^{2}(.971)$ implies that ratio of Net NPA to Net advances explain $97 \%$ of the total variance. The negative sign of regression coefficient indicates that there is a negative relationship between the DV and IV. Thus, it can be concluded that the NPAs has an inverse impact on the Return of Assets (ROA) i.e., if NPAs of the Indian banks decreases, the profitability will increase when other factors will remain unchanged.

Similarly, research model $1 \mathrm{~b}$ represents the result of regression analysis between the Return on Equity (ROE) and ratio of Net NPA to Gross advances (NPA). The model is $R O E_{I}=\alpha+$ $\beta(\mathrm{NPA})+\varepsilon$, where Dependent Variable is ROE and Independent Variable is ratio of Net Non-Performing Asset to Net advances (NPA). The F value of this model is 44.351 which is significant at $1 \%$ level of significance. The $R$ value (.948) signifies high correlation between DV and IV. On the other hand, value of $R^{2}$ (.899) indicate that ratio of Net Non-Performing Asset to Net advances (DV) explain almost $90 \%$ of the total variance. The negative sign of regression coefficient indicates that there is an inverse relationship between the DV and IV. Thus, it can be concluded that the NPA has an inverse relation with the Return of Equity (ROE) i.e., if NPA of the Indian Banks increases the profitability will go down when other factors will remain same.

Table.2. Regression Result for Bangladesh Banks

\begin{tabular}{|c|c|c|c|c|c|c|}
\hline \multirow{2}{*}{\multicolumn{2}{|c|}{ Model }} & \multicolumn{2}{|c|}{$\begin{array}{l}\text { Unstandardized } \\
\text { Coefficients }\end{array}$} & \multirow{2}{*}{\begin{tabular}{|c|}
$\begin{array}{c}\text { Standardized } \\
\text { Coefficients }\end{array}$ \\
Beta
\end{tabular}} & \multirow{2}{*}{$\mathbf{t}$} & \multirow{2}{*}{ Sig. } \\
\hline & & B & $\begin{array}{l}\text { Std. } \\
\text { Error }\end{array}$ & & & \\
\hline $\begin{array}{c}\text { Research } \\
\text { Model } \\
2 \mathrm{a}\end{array}$ & $\begin{array}{c}\text { (Constant) } \\
\text { NPA }\end{array}$ & $\begin{array}{l}3.666 \\
-.318\end{array}$ & $\begin{array}{l}.682 \\
.097\end{array}$ & -.825 & $\begin{array}{c}5.379 \\
-3.264\end{array}$ & $\begin{array}{l}.003 \\
.022\end{array}$ \\
\hline \multicolumn{7}{|c|}{$\mathrm{R}=.825, \mathrm{R}$ square $=.681, \mathrm{~F}=10.654, \mathrm{P}$ value $=.022$} \\
\hline \multicolumn{7}{|c|}{$\mathrm{DV}=\mathrm{ROA}, \mathrm{IV}=\mathrm{NPA}$} \\
\hline $\begin{array}{c}\text { Research } \\
\text { Model } \\
2 \mathrm{~b}\end{array}$ & $\begin{array}{c}\text { (Constant) } \\
\text { NPA }\end{array}$ & $\begin{array}{l}47.132 \\
-5.843\end{array}$ & $\begin{array}{c}20.299 \\
2.899\end{array}$ & -.670 & $\begin{array}{l}18.422 \\
-6.660\end{array}$ & $\begin{array}{l}.000 \\
.001\end{array}$ \\
\hline \multicolumn{7}{|c|}{$\mathrm{R}=.670, \mathrm{R}$ square $=.448, \mathrm{~F}=4.064, \mathrm{P}$ value $=.010$} \\
\hline & & $\mathrm{DV}=$ & 1 & & & \\
\hline
\end{tabular}

The Table. 2 shows the results of regression analysis of listed Bangladesh Banks. The Research model 2 a represented the output of regression analysis, where the dependent variable (DV) is Return on Assets (ROA) and independent variable (IV) is ratio of Net NPA to Net advances (NPA). The model is: $R O A_{B}=\alpha+$ $(\mathrm{NPA})+\varepsilon$.

The $\mathrm{F}$ value of this model is 10.654 which is significant at $5 \%$ level of significance. The $\mathrm{R}$ value $(.825)$ indicates that high correlation between variables and value of $\mathrm{R}^{2}(.681)$ implies that ratio of Net NPA to Net advances explain $68 \%$ of the total variance. The negative sign of regression coefficient indicates that there is a negative relationship between the DV and IV. Thus, it can be concluded that the NPAs has an inverse impact on the Return of Assets (ROA).
Similarly, research model $2 \mathrm{~b}$ represents the result of regression analysis between the Return on Equity (ROE) and ratio of Net NPA to Gross advances (NPA). The model is $R O E_{B}$ $=\alpha+\beta(\mathrm{NPA})+\varepsilon$, where Dependent Variable is ROE and Independent Variable is ratio of Net Non-Performing Asset to Net advances (NPA). The F value of this model is 4.064 which is significant at $1 \%$ level of significance. The $R$ value (.670) signifies correlation exist between DV and IV. On the other hand, value of $\mathrm{R}^{2}$ (.448) indicate that ratio of Net NonPerforming Asset to Net advances (DV) explain almost $45 \%$ of the total variance. The negative sign of regression coefficient indicates that there is an inverse relationship between the DV and IV. Thus, it can be concluded that the NPA has an inverse relation with the Return of Equity (ROE).

\section{CONCLUSION}

In a nutshell, researchers can conclude that the growth of NPAs in Indian public sector banks as well as Bangladesh State owned banks are dramatically upward rising while private sector banks in both the countries are more conscious about the NPAs as well as total advances. The trends of NPAs are found to be more stable during the study period for private banks in both the countries. It is also revealed in the study that the Non-Performing assets have an adverse impact on the profitability for both types of banks in India as well as Bangladesh and it creates more serious problems in public sector bank rather than the private sector banks. Thus, overall fact is that the profitability of the bank gets upward trends if there is downward movement of the NonPerforming assets in the bank and vice versa. Therefore, the management of the banking sector more specifically public banks, should take some preventive and recovery strategy to minimise and control nonperforming assets to sustain and there is a need to modify the client assessment procedure. So it is suggested that the management of the banking of both the countries sector should be focused on the nature of the client rather than the signature to maximise profitability.

\section{REFERENCES}

[1] B.K. Adhikari, "Nonperforming Loans in the Banking Sector of Bangladesh: Realities and Challenges", Bangladesh Institute of Bank Management, pp. 75-95, 2007.

[2] S. Alam, M. Haq and A. Kader, "Nonperforming Loan and Banking Sustainability: Bangladesh Perspective", International Journal of Advanced Research, Vol. 3, No. 8, pp. 1197-1210, 2015.

[3] C.S. Balasubramaniam, "Non-Performing Assets and Profitability of Commercial Banks In India: Assessment and Emerging Issues", ABHINAV National Monthly Refereed Journal of Research in Commerce and Management, Vol. 1, No. 7, pp. 41-52, 2012.

[4] B. Selvarajan and G. Vadivalagan, "A Study on Management of Non-Performing Assets in Priority Sector reference to Indian Bank and Public Sector Banks (PSBs)", Global Journal of Management and Business Research, Vol. 13, No. 1, pp. 1-14, 2013.

[5] K. Kiran and M. Jones, "Effect of Non-Performing Assets on the Profitability of Banks-A Selective Study", 
International Journal of Business and General Management, Vol. 5, No. 2, pp. 53-60, 2016.

[6] Rabeya Sultana Lata, "Non-Performing Loan and Profitability: The Case of State Owned Commercial Banks in Bangladesh", World Review of Business Research, Vol. 5. No. 3, pp. 171-182, 2015.

[7] Laveena and Kumar Hitesh, "Management of NonPerforming Assets on Profitability of Public and Private Sectors Banks", International Journal of Research in Management and Technology, Vol. 6, No. 2, pp. 86-93, 2016.

[8] M. Rao and A. Patel, "A Study on Non-Performing Assets Management With Reference to Public Sector Banks,
Private Sector Banks And Foreign Banks in India”, Journal of Management and Science, Vol. 5, No. 1, pp. 30-44, 2015.

[9] V.R. Singh, "A Study of Non-Performing Assets of Commercial Banks and its Recovery in India", Annual Research Journal of SCMS, Vol. 4, pp. 110-125, 2016.

[10] K. Srinivas, "A Study on Non- Performing Assets Of Commercial Banks In India", Abhinav International Monthly Refereed Journal of Research In Management and Technology, Vol. 2, No. 3, pp. 61-69, 2013.

[11] N. Sonia and M. Singla, "Empirical Study on NonPerforming Assets of Bank", International Journal of Advance Research in Computer Science and Management Studies, Vol. 2, No. 1, pp. 194-199, 2014. 